\title{
PUNIÇÃO, DISCIPLINA E PENSAMENTO PENAL NO BRASIL DO SÉCULO XIX*
}

Andrei Koerner

O presente artigo apresenta uma análise das práticas punitivas na sociedade escravista brasileira do século XIX, com o objetivo de esboçar a tecnologia política do corpo daquela sociedade e suas conseqüências para o pensamento jurídico penal. Tomando como ponto de partida as características institucionais da Casa de Correção da Corte (CCRJ), apresentam-se as suas articulações com outras práticas punitivas da sociedade escravista brasileira. A análise concentra-se nas relações entre as práticas punitivas estatais e as estratégias de produção da submissão produtiva dos indivíduos naquela sociedade. Colocam-se em relevo as especificidades das relações de poder e as formas de saber em uma sociedade escravista, a qual adota, na década de1820, a forma política de um Estado constitucional. Essas especificidades manifestam-se no pensamento penal brasileiro do século XIX.

\footnotetext{
* Trabalho preparado para o "Colloque 30 ans après Surveiller et punir de Michel Foucault: repenser le droit de punir", realizado na Universidade de Genebra, em fevereiro de 2006. Este artigo é uma versão substancialmente modificada de trabalho anterior, publicado na Revista Brasileira de Ciências Criminais, n. 35, jul./set. 2001
} 
A análise é orientada pelas regras gerais que Foucault propõe, em Surveiller et Punir, para o seu trabalho: a de "tomar a punição como uma função social complexa"; a de "analisar os métodos punitivos como técnicas que têm sua especificidades no campo mais geral dos procedimentos de poder"; a de "buscar se não há uma matriz comum [entre a história do direito penal e a das ciências humanas] e se elas não relevam, conjuntamente, de um processo de formação epistemológico-jurídica" que se dá por meio das tecnologias de poder; e, enfim, a de "buscar se essa entrada da alma na cena da justiça penal, e com ela a inserção na prática judiciária de todo um saber “científico” não é o efeito de uma transformação da maneira pela qual o corpo é investido pelas relações de poder". Foucault sintetiza sua proposta como "tentar estudar a metamorfose das metodologias punitivas a partir de uma tecnologia política do corpo onde seria possível ler uma história comum 206 das relações de poder e das relações de objeto" (Foucault, 1975: 28).

Considerando-se as tensões entre formas jurídicas liberais e as características de uma formação social escravista colocam-se diversas questões: como se articulam as práticas punitivas estatais, sociais e domésticas? Quais as punições aplicadas sobre os sujeitos, em função de seus diferentes estatutos jurídicos e posições sociais? Como as formas do Estado constitucional e as categorias das ciências humanas se incorporam às práticas de dominação e às relações de objetos já estabelecidas na sociedade escravista?

A análise que segue trata a tecnologia política do corpo submisso e produtivo como uma estratégia de conjunto que combina, do lado das práticas de subordinação, formas jurídicas modernas, práticas punitivas estatais e a disciplina escravista; e, do lado das relações de objeto, a conjugação do pensamento jurídico e do conhecimento das ciências humanas com os saberes práticos constituídos e reprodu- 
zidos no exercício do poder sobre os sujeitos escravizados. Não se pretende, neste artigo, caracterizar essa tecnologia do corpo em seu conjunto, mas apenas esboçar alguns de seus aspectos referidos às práticas punitivas, disciplina escravista e pensamento jurídico.

Inicialmente, apresentam-se as características da Casa de Correção da Corte (1), para, em seguida, analisar as suas características institucionais como parte da configuração das estratégias de produção da aquiescência desenvolvidas pela sociedade escravista brasileira no século XIX (2). No momento seguinte, apresenta-se a disciplina escravista, comparando-a com o suplício e a disciplina normalizadora (3). Enfim, analisam-se alguns pontos do discurso jurídico penal brasileiro (4).

\section{A Casa de Correção da Corte em 1874}

A partir da independência política, em 1822, as colônias da América portuguesa organizaram-se num único Estado, construído sob a forma de uma monarquia constitucional. A preservação da escravidão foi o fator fundamental para a unidade política das colônias, tanto devido aos riscos que as guerras de Independência representavam para a instituição (riscos de sublevação dos escravos, de mobilização de escravos em troca de sua manumissão), como à necessidade de reconhecimento internacional do novo Estado. A Inglaterra não reconheceria novas repúblicas americanas escravistas, e pressionava as autoridades brasileiras pela extinção imediata do tráfico transatlântico de escravos africanos. Assim, a organização política de um Império sob a casa de Bragança, que mantinha vínculos familiares com os Habsburg, representava uma sustentação política européia, em face das pressões inglesas e diante das repúblicas vizinhas da América espanhola. O novo Estado consolidava, pois, uma aliança de elites políticas regionais, funcionários do Estado, comerciantes e proprietários de terras, em torno da preservação e 
reordenamento das relações escravistas no quadro de uma ordem nacional (Alencastro 1979).

Na organização política do novo Estado, adotou-se, dentre outras formas jurídicas do liberalismo político, uma Constituição com separação de poderes, organizados segundo os princípios da representação política baseada em voto censitário e da independência do Poder Judiciário, e a declaração de direitos e garantias fundamentais. $\mathrm{Na}$ Declaração de Direitos (art. 179), a Constituição adotou os princípios da responsabilidade individual pelos crimes e da legalidade. Aboliu, para os cidadãos, as penas de açoites, torturas, marcas de ferro quente e qualquer pena cruel. Também previu a elaboração de um código civil e penal, o que ocorreu com a promulgação do Código Criminal em 1830 e o Código de Processo Criminal em 1832, baseados nas doutrinas iluministas do direito de punir. As penas eram a condenação à morte, à prisão, simples ou com trabalho, às 208 galés ${ }^{1}$, ao degredo, ao banimento, ao desterro, a multas e à suspensão ou perda de emprego público.

A Constituição também determinava que as prisões fossem seguras, limpas e bem arejadas, havendo separação dos réus, de acordo com sua classificação penal e a natureza dos seus crimes. Isso implicava a construção de Casas de Correção para os condenados à prisão, Casas de Detenção para os detidos sujeitos a processo penal, além de outros estabelecimentos destinados aos alienados, aos menores e aos detidos por vadiagem e contravenções menores. Quanto aos escravos, um único artigo do Código Criminal (art. 60) determinava que, quando não fossem condenados à morte ou às galés, suas penas seriam comutadas em açoites, sem prejuízo de serem obrigados a trabalhar presos a ferros nas

1. Pena de trabalhos forçados em locais públicos, com os condenados presos a ferros, individualmente ou em grupo. 
fazendas de seus proprietários ou estabelecimentos públicos. Em resposta às rebeliões de escravos no início da década de 1830, a Lei de 10.6.1835 ampliou os casos de pena de morte para escravos, estabelecendo-a para os que atentassem de algum modo contra a integridade física de seus senhores, representantes ou familiares, ou que promovessem qualquer forma de rebelião ou desobediência coletiva. A condenação seria tomada pelos júris locais, sem direito a apelação ou pedido de graça. Porém, como a execução da pena de morte dependia de confirmação do Imperador, a partir de meados da década de 1850, ele comutava as condenações à morte por penas de galés perpétuas.

Até a Independência, as cadeias eram administradas pelas Câmaras dos municípios. Na maior parte das vilas, elas eram instaladas em cômodos ou casas alugadas, enquanto em vilas e cidades maiores ficavam no próprio edifício da Câmara. Em caracterização resumida, as cadeias públicas municipais eram depósitos de pessoas, sem segurança contra fugas nem condições de higiene, e nelas eram recolhidos indivíduos de todo tipo, desde pessoas livres condenadas, que respondiam a processo criminal ou em prisão civil, até escravos ou negros suspeitos de serem escravos fugidos, e também vadios, loucos, índios, prostitutas, bêbados etc. Poderiam ser enxovias, como em São Paulo, onde, a partir de 1787, havia um prédio de dois pavimentos, em que a Câmara funcionava no andar superior e a cadeia, no inferior. Todos ficavam numa mesma sala; para as pessoas de condição (como homens livres com propriedade ou prestígio local e funcionários) havia acomodações distintas. Os presos faziam trabalhos públicos, circulando sob vigilância ou presos a ferros e correntes, se condenados às galés (Salla, 1999: 36-40). As condições das cadeias públicas continuaram as mesmas durante todo o século XIX, e as penitenciárias, situadas em algumas capitais, não tinham condições sanitárias muito melhores, embora nelas fosse ensaiada a 
separação dos presos e a adoção de regimes disciplinares para sua reforma moral.

Em 1830, havia mais de trinta prisões no Rio de Janeiro, incluindo as militares, situadas em fortes, as eclesiásticas, a naval (um navio ancorado no porto com 458 condenados por crimes mais graves, sentenciados a trabalhos forçados, e escravos fugidos), e as prisões civis, como as do Aljube, de Santa Bárbara, da ilha das Cobras, do Calabouço do Castelo (Karasch, 2000: 176-178). O Calabouço era a prisão onde os escravos eram presos e recebiam açoites, como pena pública ou como castigo privado, executado por demanda do proprietário. Até 1829, os açoites eram aplicados em praças públicas, quando então foram deslocados para o Calabouço, permanecendo no espaço público os açoites aos criminosos condenados por sentença e os capoeiras. Dentre os encarcerados, a pior condição era reservada aos escravos, que recebiam alimentação e vestuários da pior qualidade e deviam

210 trabalhar em serviços externos e prestar serviços aos outros presos. Além dos escravos condenados, havia aqueles detidos para "correção" por seus donos e que corriam o risco de ficarem ali abandonados para o resto de suas vidas, pois não podiam sair da prisão sem o consentimento de seus donos, uma vez que o governo não podia perdoá-los porque não haviam sido condenados (Karasch, 2000). Os escravos depositados também acabavam abandonados na prisão quando a dívida de seus donos com a taxa de manutenção excedia o seu valor (Salla, 1999: 85-86). Outro grupo era o dos escravos fugidos, aqueles cujos donos se recusavam a libertá-los para puni-los da fuga, ou os que não revelavam os nomes de seus donos nem mesmo sob tortura. Então, ficavam nas prisões à espera da reclamação por parte de seus proprietários. Havia, ainda, os africanos livres, libertados do tráfico ilegal pelas operações das marinhas inglesa e brasileira na década de 1830. Eles foram emancipados pelo governo brasileiro, mas a sua condição acabou sendo igual à dos escravos, visto 
que foram deixados sob guarda de grandes proprietários de escravos ou ficaram a cargo das autoridades prisionais, para executar serviços públicos (Karasch, 2000: 178-179; Salla, 1999). A CCRJ recebeu-os desde o início do seu funcionamento e, em 1852, eram 677 africanos ali alojados (Conrad, 1985: 176).

É neste contexto que, em 1833, o governo imperial toma as providências para a construção de uma Casa de Correção na Corte ${ }^{2}$. Adotou-se um projeto elaborado em 1826 por uma sociedade inglesa de melhoramento das prisões, o qual previa uma construção "estilo panóptico", com quatro raios, com duzentos cubículos cada um, totalizando 800 celas. Em cada raio haveria quatro andares, que comportariam cinqüenta cubículos por andar, cada qual com 2,64 m de comprimento, 1,65 m de largura e 3,08 de altura, totalizando $4,3 \mathrm{~m}^{2}$. As celas seriam distribuídas ao longo de um corredor central, havendo também corredores externos. Como regime disciplinar, adotava-se o trabalho em comum durante o dia, em completo silêncio, e isolamento à noite nos cubículos (Alburn). As oficinas seriam intercaladas com os raios, enquanto, na torre central, se situariam a casa do diretor e a capela.

Entretanto, de acordo como o Relatório da Comissão Inspetora da Casa de Correção da Corte de 1874 (Relatório, 2001), a prisão tornou-se bastante diferente do modelo concebido pelo projeto. Como se sabe, a construção panóptica é destinada a permitir que, da torre central, haja completa visibilidade do estabelecimento. O Relatório ressalta esse aspecto e apontava os cuidados que deveriam ser tomados, a fim de permitir a completa visibilidade. As galerias de circulação deveriam ser abertas desde o térreo até o último andar do edifício e deveriam ser largas para possibilitar a iluminação e a ventilação, assim como o acesso imediato dos guardas a todos os pontos

2. Salvo outra referência, as informações que seguem são baseadas no Relatório de 1874 (Relatório, 2001). 
do estabelecimento. Porém, esses cuidados não foram tomados na construção do edifício, que apresentava muitos erros de execução. Os corredores não eram abertos em toda a altura do edifício, pois eram cortados pelas lajes que separavam os andares. Essas lajes bloqueavam a visão, dos guardas, que, desse modo, não percebiam o movimento dos condenados nas celas e dos corredores situados em andares diferentes daquele em que estivessem situados. O corredor central do raio era muito estreito, e os corredores externos tinham janelas pequenas, prejudicando a iluminação das celas. Assim, por um hipotético observatório central, o guarda conseguiria ver, com dificuldade, apenas os corredores das celas do mesmo andar em que ele estivesse, dada a semi-obscuridade do corredor e das celas.

A CCRJ sempre recebeu presos de todo tipo, em virtude do excesso de lotação nas outras prisões da cidade. No espaço interior das suas muralhas foram construídos dois raios de oficinas, bastante exíguas, para os trabalhos dos presos. Foram 212 também feitas "obras extraordinárias e provisórias": dois calabouços para os condenados a galés, duas oficinas e, ainda, o calabouço para escravos e um depósito de africanos livres, o colégio dos menores, uma seção dos bombeiros e a casa da administração do presídio. Nos edifícios das oficinas havia instalações para alienados com três celas para "loucos furiosos". As instalações compreendiam, ainda, as masmorras, destinadas à punição de prisioneiros.

O regime disciplinar adotado pela CCRJ foi criticado desde o início de sua construção. Alguns juristas defendiam o regime de isolamento total, com cela individual, obrigação de silêncio e trabalho solitário na cela durante o dia. Outros consideravam muito duro o isolamento e a regra do silêncio e propunham a adoção de um regime com a separação dos condenados em classes, com trabalho em comum. Decidiu-se, então, testar todos os regimes disciplinares, mantendo-se, provisoriamente, o regime de Alburn no Regulamento do primeiro raio. Essa solução foi justificada pela necessidade de "pro- 
ceder sem precipitação" e "deixar o tempo habilitar" o regime mais adequado.

Terminada a construção do andar térreo do primeiro raio, em 1835, para ela foram transferidos alguns condenados, escravos e africanos livres. À medida que terminava a construção dos outros andares, os condenados eram transferidos para eles e, mais tarde, para cubículos nas mansardas (sótão), mantendo-se os escravos e africanos livres no térreo. Assim, na falta de outros estabelecimentos prisionais na cidade, foram aglomerados no edifício ainda nascente "presos e sentenciados de todas as espécies com prejuízo da disciplina, por melhor que fosse o regime adotado, e com perturbação do plano, que aliás começara errado".

O segundo raio da CCRJ, cuja construção começou em 1854, apresentava uma arquitetura bastante diferente. Tinha capacidade para 160 detentos, que seriam distribuídos em 40 celas individuais de $14,6 \mathrm{~m}^{2}$ no térreo e 20 salas de $30 \mathrm{~m}^{2}$ no andar superior, destinadas a até 6 presos por cela. Com apenas dois andares, com 15,18 $\mathrm{m}$ de altura e 67,6 m de comprimento, era menor do que o primeiro raio, que possuía quatro andares, de 16,5 m de altura e comprimento de 60,16 m. Assim, o novo raio "penetrou pelo terreno destinado à área de comunicação com a torre central”, a qual não teria mais espaço para ser construída. Além disso, o novo raio não recebeu condenados à prisão com trabalho, mas acusados ainda não condenados, com o processo criminal em andamento, transferidos da prisão do Aljube, que ameaçava ruir. As salas individuais do primeiro andar eram destinadas a testar o regime de isolamento total, mas era um contra-senso aplicar esse regime a presos ainda não condenados e, assim, os presos permaneceram em celas comuns, sem trabalho. Com o tempo, como não havia vagas para o cumprimento da prisão com trabalho no primeiro raio da CCRJ, os presos condenados a essa pena cumpriam a pena no segundo raio, isto é, em regime de prisão simples, enquanto aguardavam vaga no primeiro raio. 
É no plano das condições sanitárias e de higiene que a CCRJ parecia estar mais distanciada de seu projeto original. Condições de salubridade adequadas eram, sem dúvida, pressupostos para a reforma moral dos condenados e, por isso, as prisões norte-americanas e inglesas melhoraram as condições sanitárias e de higiene a partir de meados do século XVIII. A taxa de mortalidade em prisões inglesas era de 1,08\% em 1877 e de 0,56\% em 1896 (Rusche e Kirchheimer, 1939: 150, apud, Salla, 1999: 109). A CCRJ não tinha água encanada, esgoto ou instalações adequadas para os banhos dos presos. Como não havia enfermaria, os doentes eram instalados em algumas das celas, sem qualquer separação para os enfermos de doenças contagiosas. Devido à localização e à má construção do prédio, era insuficiente a ventilação das celas. Essas condições traziam conseqüências nefastas à saúde dos presos, pois, segundo a Comissão, dos 1.099 condenados recolhidos ao estabelecimento entre 214 junho de 1850 e dezembro de 1869, 245 faleceram. Dos 656 presos com penas maiores de dois anos, 236 haviam falecido, ou $36 \%$. Entre os condenados a mais de 8 anos, a mortalidade era superior a $40 \%$ e, dos 32 condenados a penas maiores que 20 anos, 27 morreram, dois foram perdoados, dois removidos e o restante começara a cumprir pena a menos de um ano. O diretor do estabelecimento, que ali trabalhava há dez anos como médico, considerava que a condenação a uma pena maior de dez anos equivalia a uma sentença de morte. Os poucos que cumpriam esse tempo deixavam a prisão com lesões graves, que os incapacitavam para qualquer ocupação útil.

Em relação à "condição moral, religiosa e instrutiva dos presos”, havia um capelão católico, que dizia missas e dava assistência a eles. O serviço de educação só fora implantado há pouco tempo pelo capelão, o qual ensinava "rudimentos de gramática e aritmética" a cerca de um terço dos presos. As oficinas estavam instaladas e funcionavam com turmas de dez 
a vinte condenados, cada qual com um mestre que dirigia o trabalho. Devido a essa desproporção, não se conseguia manter o controle do silêncio rigoroso dos condenados.

A Comissão de 1874 propunha melhorias nas condições de encarceramento que reduzissem o sofrimento e a mortalidade dos presos. Defendia a melhoria das instalações e dos serviços, propunha a transferência dos presos cuja condenação não os sujeitasse ao regime da CCRJ para outros estabelecimentos e sugeria o relaxamento do regime disciplinar para os presos de melhor comportamento, aos quais deveria ser permitido passear em um espaço da prisão destinado ao exercício de outros prisioneiros. Porém, as suas propostas de reforma jamais foram implementadas, assim como as propostas de outras comissões de inspeção das décadas seguintes. Em 1903, uma comissão de inspeção relatava que as instalações da CCRJ eram as mesmas de trinta anos antes e seu regulamento ainda mantinha "provisoriamente" o regime Alburn. Avaliava que o estabelecimento era "um depósito de presos onde tudo é permitido e desordenado". Ele era comandado de fato pelo chefe dos guardas, "violento e sem escrúpulos", que utilizava revoltas dos presos para "desmoralizar a administração". A comissão julgava que a CCRJ "não tem administração, não tem sistema, não tem moralidade, ou melhor, não há Casa de Correção" (E. Moraes, 1923: 64-68). Em 1923, Lemos Brito descreve as condições da CCRJ em termos semelhantes aos das comissões anteriores: não havia nenhum rigor na aplicação do isolamento ou silêncio dos presos (Brito, 1925: 198-202). Noutras prisões da República, a situação não era diferente ${ }^{3}$.

3. Sobre as condições das prisões na Primeira República, ver Brito (1924, 1925 e 1928); sobre as cadeias de São Paulo, veja Salla (1999); sobre a Casa de Detenção do Recife, ver Huggins (Salla, 1999: 79 et passim); sobre o Presídio de Fernando de Noronha, G. Pessoa (1994); sobre o estado das prisões na Corte e em outras Províncias, Algranti (1988) e Aufderheide (1976: 314 et passim). Em geral, há, nos Relatórios do Ministério da Justiça de todos os anos, considerações sobre o estado precário das prisões do Império e a necessidade de reformá-las. Esta preocupação acentuou-se a partir da década de 1870 . 


\section{Disciplina e prisão na sociedade escravista}

A análise da confusão e precariedade aparentes da CCRJ, o principal projeto de penitenciária panóptica brasileira, permite identificar suas relações com outras práticas punitivas estatais e estratégias de produção da submissão produtiva na sociedade escravista brasileira do século XIX.

A CCRJ não constitui um espaço institucional fechado, homogêneo e ordenado segundo as regras propostas pelo projeto reformista. Ela é permeada por regras, prioridades e decisões que lhes são exteriores, cuja racionalidade a atravessa. Tal como outros estabelecimentos militares e administrativos, ela concentra diversas funções e seus dirigentes recebem uma delegação ampla, acumulando as mais diversas atribuições e com autonomia quase completa na resolução dos problemas cotidianos, particularmente aqueles envolvendo a manutenção da ordem entre os subordinados. Porém, escapava-lhes a determinação das funções,

216 regras e prioridades do estabelecimento, estipuladas por outros. Mas não se trata de incompletude, pois o estabelecimento é constituído e ordenado por uma racionalidade cujo propósito é garantir, de imediato, a continuidade das relações sociais existentes. Esses limites determinam as características da instituição e o campo de possibilidades a ser alcançado pelas iniciativas reformistas. Como afirma um autor, é preciso, em primeiro lugar, garantir a ordem social e só num segundo momento pensar em recuperar os criminosos (Bandeira, 1881: 32). As reformas acabam por ser colocadas como uma alternativa à ordem, e não como uma variante dela, e assim seu destino é o de jamais serem implementadas.

A construção da CCRJ recebeu importantes mudanças na arquitetura em "estilo panóptico" em relação ao projeto original. A disposição interior/exterior do conjunto de edifícios é diferente, pois estes não se agrupam num só conjunto arquitetônico homogêneo. Pelo contrário, os raios, 
oficinas e outros edifícios tornam-se edificações independentes, que apenas compartilham um mesmo espaço. Desaparece, então, o espaço homogeneizado do panóptico, com suas divisões claras das posições ocupadas pelos vigilantes e vigiados e o controle simbolizado por uma instância central, que se exerce de uma forma impessoal e quase virtual. Os espaços vazios entre os raios são ocupados por edificações de vários tipos, dispostas de forma assimétrica, improvisada. Além disso, essas edificações são destinadas a atividades diversas das previstas no plano original, embaralhando a distribuição das posições de vigilantes e vigiados. A CCRJ propriamente dita não mais abarca todo o espaço no interior das muralhas, mas apenas a parte que é ocupada pelo primeiro raio e por suas oficinas, enquanto o espaço restante se torna gradualmente parte de outro estabelecimento.

Assim, nem tudo poderia ser visto de uma hipotética torre central. Caso ela fosse erigida, não permitiria ver mais do que uma pequena parte dos espaços interiores desses edifícios, os quais tinham como característica comum bloquear a visão externa. Como esta arquitetura não tem os atributos de visibilidade da máquina panóptica, ela não é capaz de produzir os mesmos efeitos daquela sobre o comportamento dos condenados. Por isso, impõe a presença permanente dos vigilantes no interior de cada edifício, a qual é indissociável da exibição - e utilização - de seus instrumentos de violência, considerados o único meio de obter a obediência dos prisioneiros.

As práticas disciplinares da CCRJ combinam as categorias do direito penal com as de classificação social dos indivíduos. A CCRJ do século XIX não é mais apenas um depósito de pessoas, tal como as prisões do tempo colonial, pois nela as categorias do direito penal iluminista incidem sobre as categorias que traduziam sua condição social (seu estatuto jurídico e propriedade). O estatuto jurídico continua a ser, evidentemente, o critério mais importante de classificação 
dos presos. Isso é evidenciado pelo fato de que os escravos e africanos livres ocupavam os piores lugares, pois a eles eram atribuídas as celas do térreo e do sótão - os lugares mais insalubres, devido à umidade e ao calor -, cabendo as células dos andares intermediários para os presos com estatuto jurídico de homem livre. Devido ao número limitado de vagas no primeiro raio e à diversidade dos regimes disciplinares das diferentes edificações, a direção podia distribuir a presos condenados à mesma pena localizações e atividades bastante diferentes. Assim, os detidos na CCRJ não estão dispostos num espaço analítico homogêneo nem estão depositados coletivamente, formando uma massa confusa e informe. Há uma disposição analítica que os individualiza, por meio de critérios compostos, que compreendem tanto as categorias do pensamento penal quanto às de classificação social. É, assim, um espaço analítico heterogêneo no qual vigora uma individualização hierarquizada dos detidos.

218 No interior das muralhas há uma contínua circulação de indivíduos. Isso se deve à diversidade dos prisioneiros, pois há aqueles que fazem trabalhos externos ou que ali estão temporariamente, em prisão preventiva ou detenção correcional. Essa circulação também resultava do efeito da ação da polícia nas ruas da Capital, que, para controlar a circulação e as atividades dos escravos, detinha sistematicamente indivíduos suspeitos (negros e mestiços, escravos, libertos ou livres pobres $)^{4}$. Desde a época colonial, as cidades eram um espaço de recepção de indivíduos livres e pobres. Dada a estrutura social escravista, era limitado o espaço para o trabalho assalariado e, assim, esses indivíduos buscavam aproveitar as precárias oportunidades de ganho econômico nas cidades. Porém, eles eram tratados como vadios e des-

4. As exposição desse e dos próximos parágrafos, baseia-se em Aufderheide (1976: 99), Holloway (1993: 114), Algranti (1988: 34-35, 40), Chaloub (1990) e Fraga Filho (1996: 84). 
classificados, porque não eram proprietários nem trabalhadores manuais, ao mesmo tempo que não estavam inseridos em relações de dependência pessoal com os proprietários, sendo assim indivíduos não-localizáveis na estrutura social escravista (veja Kowarick, 1994; L. M. Souza, 1986). Com o crescimento das cidades, os escravos confundiam-se com a população de cor em geral, tornando-se mais difícil distingui-los dos livres e libertos. Os indivíduos negros ou pardos eram antes de tudo suspeitos, e a polícia os detinha com o objetivo de verificar se eram escravos. O controle manifestava-se de diversas formas, como as rondas noturnas, que detinham sem maiores explicações negros que circulavam na cidade após o toque de recolher, os regulamentos sobre o porte de armas, a venda de bebidas alcoólicas, a proibição da prática da luta de capoeiras. A polícia utilizava ad hoc a criminalização da vadiagem, o que lhe permitia controlar a circulação dos indivíduos suspeitos e impor vigilância contínua sobre o comportamento dos indivíduos pobres ${ }^{5}$.

Como não se completa a diluição do vigilante num olhar invisível, ele não se oculta de forma insidiosa nos esquemas arquiteturais, ou nas práticas difusas de adestramento dos corpos dos indivíduos. Os efeitos que seriam provocados pela máquina panóptica estão neutralizados, ou pelo menos transformados, neste (impossível) "panóptico tropical-escravista”. Embora também utilize as técnicas disciplinares, o vigilante mantém-se personificado, visível, concreto e próximo, como uma ameaça para os subordinados. Isso indica a correspondência entre a forma de vigilância da Casa de Correção e a das ruas com a forma geral das relações de controle social da sociedade escravista, pois elas combinam distância social e proximidade física entre

5. "Vagrancy became a catchall charge that authorities used when more specific criminal acts were difficult to prove, or when they wanted to get someone off the streets and teach him or her a lesson" (Holloway, 1993: 130 et passim). 
dominantes e dominados, com suas faces complementares da proteção benevolente e da violência.

Também em relação aos trabalhos forçados podem-se fazer algumas correspondências entre as práticas prisionais, estratégias de controle e estrutura social. Vimos que os escravos e africanos livres eram obrigados a fazer os serviços de limpeza e a obedecer e servir aos outros prisioneiros. Além disso, os detidos eram aproveitados para trabalhar em serviços públicos, tanto os diários, transporte de água e de dejetos, como os de construção de obras e vias públicas. Devido à carência desse tipo de mão-de-obra, que existia desde os tempos coloniais e havia sido agravada pelo crescimento da cidade a partir do início do século XIX, a polícia do Rio de Janeiro era encarregada de fornecer trabalhadores para os serviços públicos. Os indivíduos eram detidos sem motivo ou mantidos nas prisões por mais tempo do que fixava a lei para serem aproveitados como força de traba220 lho (Algranti, 1988; Holloway, 1993) ${ }^{6}$. Os homens livres e pobres eram equiparados aos escravos, visto que todos corriam igualmente o risco de serem detidos pelas autoridades públicas e explorados por elas. Além disso, a imobilização violenta de indivíduos para a extração da sua força de trabalho, característica constitutiva da sociedade escravista, era também necessária para a construção das instalações do Estado em formação. Na CCRJ não se pretende, pois, obter a mera obediência passiva dos detidos, mas a sua submissão produtiva, embora ela não seja capaz de obter os ganhos de escala proporcionados pela máquina panóptica.

Vimos que o enclausuramento dos condenados a penas mais longas significava sua condenação à morte. A aniquilação dos escravos criminosos era funcional à socie-

6. Os próprios edifícios da Casa de Correção foram erguidos pelos condenados às galés (Moraes, 1923). 
dade escravista, pois, caso um escravo resistisse a uma longa pena de trabalhos forçados, não teria condições físicas para voltar ao trabalho, restando-lhe sobreviver da caridade pública ou do apoio de seus iguais. Além disso, ao ser condenado à morte ou às galés perpétuas, eles eram subtraídos do domínio senhorial e, caso mais tarde fosse decretada a extinção da pena, eles não retornariam à condição de cativos $^{7}$. Na lógica da sociedade escravista, não haveria um "lugar" para o escravo incapacitado para o trabalho e, assim, sua morte nos estabelecimentos prisionais, representava duplo aspecto: por um lado, o de vingança exemplar da ordem pública e senhorial tendo em vista a intimidação dos demais; e, por outro lado, o de aniquilação, para desonerar a caridade pública dos gastos com a sua manutenção.

Para os condenados de estatuto jurídico livre, essa ameaça significava que, enquanto indivíduos não-localizáveis na estrutura social escravista, eles estavam numa situação limite, sob o risco de serem submetidos a práticas punitivas estatais cujo resultado previsível era a aniquilação daqueles que caíssem em suas malhas. Assim, as garantias da declaração de direitos não alcançavam a liberdade, dignidade e (pequena) propriedade desses homens livres e pobres, que encontravam nas autoridades públicas antes uma ameaça do que uma garantia objetiva. A esses indivíduos restavam as opções de se subordinarem a alguma das formas de localização, como ter ocupação e residência fixa, ou se associarem a um proprietário por vínculos pessoais, o que lhes concedia certas "imunidades", sendo protegidos das práticas violentas de controle e qualificando-se para serem julgados segundo a perspectiva da exemplaridade e da reforma moral. Restava-lhes a alternativa de se deslocarem pelo território, em direção às fronteiras ou às cidades, correndo o

7. Aviso de 30.10.1872, apudV. Pessoa, V, 1899 [1882]: 499, n. 3206. 
risco de serem tratados como escravos fugidos, vadios, desclassificados ou errantes, caso entrassem em conflito com as autoridades públicas ou os proprietários, e serem submetidos a práticas e penas aniquiladoras.

As condições das prisões correspondem à forma de estruturação das relações sociais sob um aspecto mais geral. A melhoria das condições dos escravos nas plantações na América foi um tema de reflexão de pensadores, que mobilizaram argumentos religiosos, ilustrados ou econômicos, a fim de mostrar que era do próprio interesse dos senhores melhorar a condição dos escravos, a fim de preservar seus investimentos, obter maior capacidade de trabalho de seus escravos e estabilizar a sua mão-de-obra cativa. Porém, ao contrário de outras regiões escravistas da América, no Brasil não houve iniciativas importantes que visassem a melhorar as condições de vida dos escravos ou garantir a sua reprodução (Marquese, 2004). O sistema de plantação brasileiro do século XIX 222 manteve-se um "devorador de terras e de homens", resultando na alta taxa de mortalidade dos escravos e de homens livres. Do mesmo modo, as condições prisionais significavam o fracasso antecipado de qualquer projeto penal que visasse à reforma moral dos prisioneiros, pois elas jamais possibilitariam o "encontro com sua própria consciência" que aquela reforma pressupunha. Além disso, se eles sobrevivessem ao enclausuramento, jamais retornariam à condição de indivíduos plenamente capazes, dados os danos físicos irremediáveis que sofreram. Assim, o fracasso aparente do sistema prisional revelava a sua verdadeira função: criar um objeto para as táticas de controle e vigilância. Essas táticas tomavam como seus objetos, virtualmente, todos os homens pobres, livres ou escravos, negros ou pardos, habitantes das cidades que não dispusessem atributos de localização. Eles tornavam-se objetos e instrumentos para o exercício das ilegalidades toleradas por aquela sociedade, tornando-se úteis para as práticas de dominação em seu conjunto (Foucault, 1975). 
Enfim, do ponto de vista da produção de saberes, a CCRJ é evidentemente um dispositivo inútil para a produção de conhecimento experimental, que formula hipóteses e as testa de forma controlada, com o uso de instrumentos precisos. A prisão escravista produz um saber prático, uma espécie de ética da punição estatal numa sociedade escravista, cujos princípios, regras e máximas são recebidas, elaboradas e transmitidas por agentes de acordo com sua experiência de interações desiguais que se dão num contexto saturado de instrumentos e atos de violência. Esse saber prático combina as regras jurídicas, que atribuem estatutos jurídicos desiguais aos sujeitos, o regulamento disciplinar e as categorias sociais que diferenciam os sujeitos. Essa ética está fundada na disciplina escravista, como se verá abaixo.

Assim, em sua aparente desordem e improvisação, a CCRJ não realiza o modelo panóptico, apesar dos projetos e discursos dos reformistas do sistema pena. Ela materializa um panóptico desfigurado, impossível, visto que não tem a disposição arquitetônica nem outros atributos para produzir os efeitos e o desempenho esperados pela máquina panóptica: a obediência dos subordinados, a reprodução intensiva dos comportamentos esperados ou os ganhos de escala da vigilância. O comportamento dos detidos só é obtido por meio da imposição externa da conduta e, por isso, a vigilância deve permanecer próxima, visível e presente nos espaços; ela necessita manifestar-se em indivíduos que ostentam os instrumentos e símbolos de violência, sem os quais tem poucos recursos para obter os comportamentos esperados. Com isso, torna-se custosa, descontínua em seus efeitos e pouco eficiente.

Ela não é, porém, um projeto incompleto, pois é a resultante da incorporação de um programa de reforma moral idealizado alhures às estratégias de produção da submissão produtiva próprias a uma sociedade escravista. Ele é ilustrativo de outros projetos modernizantes implantados em nossas 
sociedades e também é revelador de suas relações de poder e formas de produção de saber. Sob esse aspecto, é necessário tratar as práticas punitivas disseminadas na sociedade, e para isso contrastamos a disciplina escravista com as duas tecnologias do poder tratadas por Foucault: o suplício e a disciplina.

\section{Disciplina escravista, suplício e normalização ${ }^{8}$}

Como se sabe, o escravismo colonial é uma dimensão da expansão dos Estados e das empresas capitalistas europeus a partir do século XVI; outras regiões do mundo foram subordinadas àqueles Estados e submetidas como colônias, integradas de modo dinâmico e subordinante aos países centrais. Na maior parte do continente americano, o processo de colonização provocou a destruição das sociedades preexistentes, com o que a ocupação do território significou a instalação de novas sociedades articuladas aos centros europeus (Novais, 1979). Elas são, pois, contemporâneas

224 à modernidade européia, mas são também descentradas e heterogêneas em relação a elas, porque se vinculam a processos políticos, econômicos e culturais que ocorrem no continente europeu e, ao mesmo tempo, desenvolvem suas próprias formas políticas e relações sociais.

Nas sociedades coloniais foi revigorada a representação da ordem política com base na distinção antiga entre poder político e poder doméstico, em que o primeiro se refere às relações entre homens livres e iguais, que se voltam aos interesses comuns ou públicos, e o segundo, às relações entre desiguais, que se dão no interior de uma propriedade, a qual é, ao mesmo tempo, uma unidade familiar e de produção. O interesse particular, ou privado, dessa unidade é comum a todos os membros da família e é representado pela vontade do seu chefe, ou pai de família.

8. A bibliografia sobre o assunto é bastante ampla, veja Lara (1979); Goulart (1971); Stein (1990). 
Nessa "arquitetura" jurídica das relações sociais, as relações políticas e as domésticas são complementares, mas incomensuráveis. Essa divisão fundamental compreende o sistema penal, no qual há delitos submetidos à jurisdição "pública" do soberano - da Coroa -, e outros que se referem às relações domésticas, nas quais prevalece o princípio da soberania do chefe de família. O sistema penal público diferencia as práticas punitivas segundo o estatuto jurídico e propriedade dos sujeitos, através de distinções que compreendem todos os aspectos das práticas punitivas, como, por exemplo, a jurisdição, os procedimentos e penas. As relações domésticas são, em princípio, excluídas da jurisdição pública e de seus procedimentos de produção da verdade. Elas são abertas ao escrutínio das autoridades públicas apenas em casos excepcionais, pela sua gravidade ou pelos seus efeitos para a própria ordem pública. A família estendida constitui, então, um espaço de não-visibilidade, de silêncio, de "não saber" público sobre as relações de poder e práticas punitivas que se dão no seu interior.

Porém, nas sociedades coloniais a divisão adquire um outro conteúdo. Inicialmente, porque a empresa colonial era um esforço coletivo que abarcava a totalidade da existência daqueles que nela se envolviam, provocando a completa redefinição de suas identidades e de sua inserção social. O estabelecimento da unidade familiar num meio ambiente desconhecido e em grande parte hostil tornava mais rarefeitos seus laços com o exterior, criando-se unidades que eram quase autárquicas do ponto de vista econômico e autocentradas em seu governo interno. Em seguida, porque, embora se organizassem sob o modelo doméstico, essas unidades eram voltadas à produção de mercadorias - produtos coloniais - para o mercado capitalista internacional, centrado na Europa. Enfim, porque a família incorporava um grande número de trabalhadores escravos, indígenas e, mais tar- 
de, africanos. Esses indivíduos eram sujeitos a uma brutal redefinição de suas identidades, em virtude da captura, das sevícias físicas, do deslocamento forçado de seu continente para as terras americanas, sem contar todas as doenças e as humilhações a que eram submetidos por traficantes e compradores de escravos. Desse modo, a unidade escravista é já um estabelecimento total, que define completamente a identidade de seus integrantes.

Assim, nas relações internas da casa, o proprietário tem o direito e o dever de praticar todos os atos necessários à preservação de sua "boa ordem”. Isso inclui, evidentemente, a execução de castigos corporais, necessários à intimidação dos subordinados e, no limite, cada proprietário adotava seu próprio sistema penal, pois, segundo uma imagem da época, cada um definia o seu próprio conjunto de delitos, graduava a sua gravidade, determinava os critérios da culpabilidade, adotava o seu processo penal particular, com pro226 cedimentos, sistema de provas e de penas.

A sociedade escravista impõe regras e comportamentos diferentes para os sujeitos, de acordo com seu estatuto jurídico e outros critérios de categorização social. Seu ponto de partida é a de uma sociedade dividida em duas ordens de sujeitos com estatutos jurídicos contrapostos: os homens livres e os escravos. Essa contraposição implica uma estratégia geral de controle: a da unificação dos homens livres tendo em vista o controle dos escravos, e vice-versa, a produção, entre os escravos, de laços de solidariedade para a resistência aos senhores. Isso implica que há regras e instrumentos que são utilizados no interior de cada uma das partes (no interior da sociedade dos senhores ou na dos escravos), e outros que só se aplicam às relações com a outra parte (entre senhores e escravos). Nessas relações, constituem-se domínios particulares de saberes, em função dos sujeitos específicos aos quais esses saberes são referidos. 
A análise que segue centra-se nas tecnologias políticas do corpo, isto é, as tecnologias de poder-saber que estão diretamente presentes nas relações entre senhores e escravos ${ }^{9}$.

As categorias jurídicas definem as relações entre senhor e escravo como relações entre sujeito-proprietário e objetopropriedade. Mas as suas relações supõem estratégias complexas para garantir a submissão produtiva dos escravos, isto é, sua obediência contínua aos senhores e seu trabalho útil na produção de bens tropicais competitivos nos mercados internacionais. Essas estratégias complexas são relações de governo, no sentido que têm como objeto a direção da conduta do outro, a circunscrição de seu campo de ações e de suas estratégias possíveis e a gestão de coletividades (Foucault, 1979 e 1984). Relativamente à conduta de si e dos outros, os senhores desenvolvem uma ética da dominação escravista que mobiliza o discurso do paternalismo, como se verá adiante. Movidas pelo objetivo da obtenção da submissão produtiva, nessas relações de poder constituise um saber dos senhores que combina saberes de origem e natureza diversas. Esses saberes referem-se à índole dos indivíduos (sua constituição física, sua capacidade de trabalho, seu comportamento em face das ameaças e punições) e dos grupos, considerados tanto do ponto de vista dos traços originários das etnias africanas (hábitos alimentares, formas familiares e religiosas, crenças mágicas) como do seu comportamento no cativeiro.

A disciplina escravista alia castigos físicos, que se assemelham aos suplícios do soberano, e técnicas normalizadoras do comportamento dos indivíduos. Os senhores utilizam uma "arte das sensações insuportáveis" desde o momento

9. A consideração completa da tecnologia política do corpo dessas colônias envolveria a discussão da estratégia global de colonização portuguesa, as relações da metrópole com o espaço colonial, a estrutura interna deste, suas diferenças com as formas de escravidão em outras regiões etc. (veja Alencastro, 1979, e Mattoso, 1995). 
em que adquirem os escravos, a fim de demonstrar, pela mais brutal desproporção da relação de forças, a sujeição destes e obter a mais completa destruição possível de sua identidade anterior. Ela também é utilizada como castigo contra toda e qualquer manifestação de insubordinação do escravo, às faltas na execução do trabalho ou ao desrespeito a quaisquer regras do estabelecimento.

Mas os castigos corporais são submetidos ao cálculo econômico do senhor, tanto para preservar o seu investimento quanto para extrair o trabalho produtivo dos seus escravos. As punições físicas devem ser limitadas, pois, como afirmavam comumente os reformadores da escravidão, castigos excessivos destroem o patrimônio do proprietário e a produtividade do seu estabelecimento (veja Marquese, 2004). O castigo corporal é utilizado para extrair trabalho produtivo dos escravos e, nesse sentido, ele é associado diretamente às técnicas disciplinares. Essas técnicas da disciplina são uti228 lizadas para controlar o comportamento dos escravos em, virtualmente, todos os momentos de suas vidas. Isso se vê na organização do trabalho e no controle dos horários, das atividades e dos locais ocupados pelos escravos. É, pois, um poder disciplinar que busca adestrar para extrair mais utilidade dos corpos, por meio da vinculação e multiplicação das suas forças. É um poder que separa, analisa, diferencia, avança os seus procedimentos de decomposição até as singularidades necessárias e suficientes. Ele é um poder cuja técnica específica toma os indivíduos, ao mesmo tempo, como objetos e instrumentos de seu exercício (Foucault, 1975: 172).

Assim, a disciplina escravista é da ordem de mecanismos difusos socialmente, com os quais se procura a ordenação das multiplicidades humanas para exercer o poder com o menor custo possível e fazer que os efeitos do poder social (sob a forma de relações escravistas) sejam levados ao seu máximo de intensidade e estendidos tão longe quanto pos- 
sível, vinculando o crescimento "econômico" do poder e o rendimento dos aparelhos no interior dos quais ele se exerce. Em suma, fazer crescer ao mesmo tempo a docilidade e a utilidade de todos os elementos do sistema (Foucault, 1975: 219-220),

Porém, dado que é escravo, o indivíduo objeto e instrumento do exercício do poder, as modalidades pelas quais essas relações de poder se exercem apresentam importantes diferenças com relação ao suplício e à disciplina. A disciplina escravista assemelha-se ao suplício pela mobilização de sinais explícitos do domínio absoluto sobre os escravos, pela utilização de técnicas aflitivas sobre o corpo, bem como pelo uso público de punições vingativas e intimidadoras em reação aos delitos. Mas eles contrastam na medida em que o suplício é utilizado pelo soberano em conjunto com procedimentos públicos de produção da verdade (Foucault, 1975: 38). Esse aspecto é menos relevante na disciplina escravista, dado o sentido utilitário e o discurso paternalista da dominação.

As técnicas da disciplina escravista têm o sentido utilitário da dominação, o cálculo dos prazeres e dores, o cuidado com os arranjos espaciais tendo em vista a maximização da produtividade que possa ser extraída dos corpos. Porém, as táticas para "ganhar a alma" dos escravos têm efeitos limitados e pouco confiáveis, o que impõe importantes adaptações das técnicas, pois a obediência dos trabalhadores não se automatiza jamais e seus gestos não possuem atributos, tais como a precisão, a constância e a regularidade. O senhor, ou seu representante, deve exercer uma vigilância visível, próxima, ruidosa, para transformar a submissão dos escravos em trabalho produtivo. Essa vigilância ostenta seus instrumentos de violência física a fim de rememorar a divisão fundadora entre senhor e escravos, e reavivar na "alma" destes os sofrimentos impostos sobre seus corpos. A proximidade dos vigilantes é indispensável para que os escravos não desperdicem seu tempo, para que os atos que lhes foram ordenados 
sejam repetidos da forma adequada, e para que haja alguém que possa corrigi-los imediatamente, ensinando-lhes, uma vez mais, a realizar corretamente os gestos mais elementares, que eles se mostram "incapazes" de aprender...

Assim, a disciplina escravista não obtém a submissão pelo temor despertado pelo éclat de um poder que manifesta de forma descontínua a diferença brutal das forças. A produtividade não é obtida com a "introjeção" da norma pelo indivíduo, que se torna o princípio da sua própria sujeição. O comportamento dos indivíduos tampouco é produzido pelo efeito de exemplos e de outras representações da pena na sua consciência. A submissão produtiva dos escravos é obtida por meio da intimidação próxima, contínua e regular, que atualiza a situação limite que ameaça sua sobrevivência e sua integridade física. A regularidade dos comportamentos do senhor e dos escravos evidencia a acomodação de suas expectativas e a configuração de uma

230 certa ordem normativa, a qual se funda nessa situação limite, cuja preservação é condição de seu exercício...

O discurso do paternalismo é adotado pelos senhores e, então, a relação jurídica de propriedade se metamorfoseia em discurso jurídico e moral da família. O senhor adota o papel do pai e atribui ao escravo o de órfão, um ser humano dotado de vontade, mas sem responsabilidade. Vê-se em operação uma relação de troca desigual de proteção contra obediência pela qual o senhor suspende a intimidação imediata sobre o escravo e este aceita a submissão produtiva. Da parte do senhor, a contenção dos atos atuais de violência comporta um engajamento implícito de que ele se conduzirá da mesma maneira no futuro. Mas ele exige do escravo a ostentação explícita, imediata, efetiva e permanente de seu labor obediente.

A regra do paternalismo não é a lei nem a norma, mas o favor (Schwarz, 1977 e 1998). Os comportamentos só se tornam regras por intermédio do julgamento subjetivo do 
senhor, cujo objeto não é tanto a determinação da verdade dos atos ou o conhecimento do indivíduo criminoso, mas a apreciação do comportamento do escravo do ponto de vista da sua adequação à preservação submissão produtiva de todos e de cada um dos escravos no interior da fazenda. Mas, à medida que as regras só se tornam conhecidas pela via da revelação casuística da vontade do senhor, elas não adquirem o caráter de enunciados normativos positivos, cujo significado possa ser determinado antecipadamente e com alguma previsibilidade pelos seus destinatários.

Assim, a disciplina escravista é um mecanismo socialmente disseminado, mas não realiza o ideal do panóptico. Ela se baseia na distribuição espacial dos pontos de exercício da vigilância, os quais põem forçosamente no campo do visível os instrumentos de violência física, necessários para manter a submissão produtiva dos escravos. Como discurso, essas relações tomam a forma do paternalismo, pelo qual se dão relações de troca entre desiguais, referidas a uma regra não enunciada, mas objetiva: a do favor do senhor. $\mathrm{O}$ favor permite o controle, pelo senhor, do sentido das regras que ordenam as relações no interior da fazenda. E essa indeterminação faz, então, parte do conjunto das estratégias de produção da submissão na sociedade brasileira do século XIX.

\section{0 discurso penal da sociedade escravista}

O discurso jurídico penal é analisado como uma reflexão prática que enfrenta o problema da construção da tecnologia do corpo da sociedade brasileira do século XIX. Ele elabora saberes e arranjos normativos com os quais são compostos, num mesmo conjunto, as formas jurídicas igualitárias do Estado constitucional e as estratégias de produção de indivíduos subordinados àquela sociedade. Essas estratégias assentam-se sobre a disciplina escravista, a qual tem, como vimos, suas próprias práticas e saberes sobre os escravos. 
Como se sabe, as formas jurídicas de um Estado constitucional e representativo produzem sua própria divisão entre o público e o privado, o seu regime de visibilidade das relações de poder social. Para isso, supõem um estatuto jurídico igualitário dos sujeitos; a concentração na autoridade pública da capacidade de dizer a lei, o monopólio, pela burocracia estatal, dos procedimentos penais e suas práticas punitivas e de produção da verdade. Vimos, porém, que essas condições eram bastante diferentes daquelas da sociedade brasileira do século XIX, na qual as formas jurídicas constitucionais sobrepõem-se às instituições e práticas de poder da sociedade escravista. Mantêm-se algumas divisões fundamentais, particularmente a soberania doméstica do senhor em relação aos seus subordinados.

A legislação penal continha regras que reconheciam o poder doméstico dos senhores. O art. 14, § 6. ${ }^{\circ}$, do Código Criminal dispunha que não seriam puníveis como crimes 232 "o castigo moderado, que os Pais derem a seus filhos, os senhores a seus escravos, e os mestres a seus discípulos”. As denúncias propostas por alguma pessoa contra seus próprios familiares ou as de escravo contra seu senhor não seriam aceitas pelas autoridades públicas (art. 75 do Código de Processo Criminal). Entre as circunstâncias agravantes da pena estava a hipótese de que o ofendido pelo crime tivesse a "qualidade de ascendente, mestre ou superior do delinqüente", ou tivesse com o ofensor qualquer relação na qual este devesse respeito filial ao ofendido", o que incluía os escravos ou libertos, que eram juridicamente classificados como órfãos, sob a tutela de seus senhores (art. 16, $\S$ 7. ${ }^{\circ}$, do Código Criminal). Enfim, o art. 60 do mesmo código, já referido, estabelecia a comutação em açoites das condenações dos escravos por crimes que não fossem punidos com a morte ou galés.

A dualidade entre senhor e escravo se traduz em lógicas punitivas diferentes. Para os homens livres adotam-se 
penas baseadas nos princípios da exemplaridade e da correção moral dos condenados, enquanto aos escravos cabem penas voltadas à intimidação e a aniquilação física. Juristas e parlamentares pensavam que as penas baseadas na exemplaridade e na correção moral dos condenados seriam insuficientes para a manutenção da ordem pública numa sociedade atrasada ou "pouco civilizada" como a brasileira. Eles constatavam que a sociedade era dividida entre livres e escravos e prognosticavam que os efeitos da exemplaridade e da correção moral, atribuídos a algumas penas, poderiam ser produzidos apenas na parcela educada da população. Para a outra parcela, eram necessárias penas com efeitos de intimidação, como a condenação à morte e às galés. Assim, os destinatários dos tipos de punição eram distinguidos em função do seu estatuto jurídico e "nível moral", cabendo as primeiras penas aos livres, proprietários e civilizados e as segundas, aos escravos e demais subordinados.

As categorias de senhor e escravo eram associadas a outras oposições como civilização e barbárie, liberdade e necessidade, garantias dos direitos e efetividade da autoridade, ordem pública e ordem doméstica, penalidade sobre a alma e castigos sobre o corpo. No discurso penal brasileiro do século XIX, os termos dessa dualidade são contrapostos, como se na prática fossem inconciliáveis. No discurso político e penal, os atributos associados aos escravos eram projetados a todos os indivíduos "desclassificados", ou nãolocalizáveis.

Isso se vê já nos debates parlamentares sobre o Código Criminal de 1830. A comissão parlamentar que relatou o projeto afirmava que desejou suprimir a pena de morte, mas decidiu mantê-la, porque "o estado atual da nossa população, em que a educação primária não pode ser geral, deixa ver hipóteses em que [a pena de morte] seria indispensável [...]”. Em discurso na Câmara dos Deputados, Paula Souza, o relator da Comissão, considerava o risco potencial de rebelião dos 
escravos e perguntava: “Quem, senão o terror da morte, fará conter esta gente imoral nos seus limites?”. Outro deputado argumentava no mesmo sentido: “[...] a nossa Pátria ainda não se acha em grau de civilização tal, que se possa admitir teorias escritas por homens filantrópicos, e aplicados a povos cuja civilização se acha no seu auge [...]"10. Outros eram céticos em relação à pena de morte, pois a consideravam incapaz de intimidar os escravos, dada a sua situação e suas crenças mágicas de regresso à África depois da morte. A solução seria adotar um código especial para os escravos, com penas corporais aflitivas, cuja forma de aplicação bastante minuciosa seria capaz de bem marcar a consciência dos escravos criminosos (Discursos na Câmara dos Deputados de setembro de 1830, apudW. Silva, 2003: 240-242).

A lógica das punições traduzia-se na agenda de reformas penais: humanizar as penas dos homens livres e agravar as penas dos escravos. Os juristas justificavam a pena de galés 234 em termos análogos aos utilizados para a pena de morte. Eles criticavam a falta de rigor na execução das penas, o que reduziria seu efeito de intimidação e incentivaria a criminalidade dos escravos, os quais prefeririam as galés ao cativeiro, dado que não estariam submetidos aos rigores do controle do senhor, levando a vida com pouco trabalho ou mesmo na "mais perfeita ociosidade". A proposta mais comum era que a pena de galés deveria ser exclusiva aos escravos, e que sua aplicação seria mais rigorosa. Isso seria obtido com a designação de trabalhos exaustivos aos condenados, que seriam realizados em estabelecimentos fechados sob estrita vigilância. Com essa restrição, evitar-se-ia a "degradação" dos homens livres condenados a essa pena, dado que ela os equiparava aos escravos (Bandeira, 1881).

10. Os casos de pena de morte para os escravos foram ampliados pela lei de 10.6.1835, referida acima. 
Noutra formulação, considerava-se que a pena de galés não intimidava suficientemente os escravos e que os açoites eram a melhor pena para eles. A legislação deveria estabelecer "base certa" para a comutação das penas, por uma correspondência entre o tempo de prisão e o número de açoites (Toledo, 1878: 635). O direito penal para os homens livres seria diferenciado daquele destinado aos escravos, mantendo-se, para ambas as categorias, uma definição clara e certa dos delitos e das penas. Outra proposta era a de unificar as penas, com a extinção das galés, deslocando-se a dualidade de objetivos das penas para o momento da execução. Em 1874, o Ministério da Justiça propunha abolir a pena de galés, generalizando-se a prisão celular com trabalho. Para os homens livres, a pena seria adequada porque exerceria sobre o criminoso ação regeneradora mais ativa e incessante; era a que melhor o educava, dando-lhe profissão e hábitos de paz. Para os escravos, a pena deveria ser a prisão celular, de dia e de noite, com trabalho e silêncio absoluto, que "não tem o caráter barbaresco da pena de galés e é, na opinião dos homens práticos, mais dura de sofrer-se que a de galés" (Relatório 2001 [1874]). Assim, o isolamento absoluto, que originariamente era voltado à reforma da consciência moral do preso, transformava-se na pena mais adequada para os escravos, por ser a mais cruel e aniquiladora. Vê-se que os juristas brasileiros estavam atualizados com o debate acadêmico europeu, no qual se propugnava o abandono puro e simples do regime de isolamento absoluto, em virtude de seus efeitos negativos para os condenados. E era precisamente por esses efeitos que seus colegas brasileiros propunham a adoção do regime de isolamento para os escravos.

A preocupação "humanitária" dos juristas era concentrada apenas nos homens livres. Essa limitação evidencia-se nas suas propostas de reforma das prisões, embora pareça, à primeira vista, que tratavam da melhoria das condições de todos os presos. Porém, quando afirmavam que a pri- 
são com trabalho era a melhor pena, e restringiam às penas de prisão suas propostas de humanização, eles tratavam de melhorar a condição dos condenados de estatuto livre, pois os escravos não eram punidos com elas. Esse é o sentido de propostas para que a CCRJ passasse a receber apenas os presos condenados a prisão com trabalho, invocando-se neste ponto o exemplo das prisões do sul dos Estados Unidos. Isso daria maior coerência ao estabelecimento prisional, mas implicava também que todos os outros detidos fossem excluídos daquele espaço, porque seriam transferidos para outros estabelecimentos, para os quais não se propunham melhorias.

A aplicação indiferenciada do regime disciplinar a todos os indivíduos nas prisões sociais era considerada inadequada e, por isso, propunha-se a sua modulação segundo a condição social dos indivíduos. Em 1854, o Ministro da Justiça, Nabuco de Araújo, afirmava que o sistema de isolamento 236 era "muito duro entre nós". A regra a adotar deveria ser "a agregação por classes, e estas com subdivisões e discricionárias como são variáveis e relativas as condições individuais. Sujeitar todos os indivíduos de qualquer classe e posição social, sendo somente detidos e indiciados, ao isolamento e ao trabalho, é repugnante aos nossos hábitos e educação, é uma violência sem razão plausível, é tornar o detido de pior condição que o condenado, sendo como é a pena de prisão com trabalho regulada pelo sistema de Alburn e a detenção conforme o sistema da Pensilvânia. Enquanto a necessidade de descobrir a verdade o exigir, seja o preso isolado; cessando esta necessidade, só devem ficar isolados os perversos, os maus, cujo contato se teme. Seja obrigado a trabalho aquele que só vive dele, o vadio, o devedor detido e outros que por motivos especiais o devam ser; aos demais seja ele livre e não imposto; assim que convirá que as celas tenham capacidade para um, dois, três e quatro presos" (apud Relatório, 2001: 268). 
Os penalistas consideravam que a separação dos presos segundo critérios de estatuto jurídico e posição social era necessária e conveniente. Uma das formas de separar os presos era mantê-los em salas distintas, como ocorria desde o período colonial. No Relatório à Assembléia Provincial de São Paulo de janeiro de 1865, Aquino e Castro relata que havia duas salas na Cadeia Pública da Capital: numa delas, que necessitava de reparos e estava imunda, eram recolhidos escravos e miseráveis, enquanto na outra, que estava em bom estado, estavam "os presos que têm condição qualificada na sociedade”. Supunha-se que a convivência entre homens livres e escravos provocaria a degradação moral dos primeiros, contrariando a finalidade reformadora das penas. A separação dos presos era então justificada da seguinte maneira: "[...] a condição diferente de hierarquia social determina a situação igualmente diferenciada sob a qual estarão submetidos os indivíduos no cárcere [...] digase embora que o que cometeu o crime é igual a outro criminoso: todavia é preciso atender que, segundo a diversidade de educações, e índoles, as mesmas penas diversificam no seu efeito, afetando mais ou menos a esse, ou aquele delinqüente, porque, por exemplo, a um homem de educação, que teve a desgraça de cometer um crime, é muito mais sensível a pena de prisão simples, do que a pretos, por gênio preguiçosos, e sem princípios de pundonor, que nessa [...] encontrarão antes um bem do que uma punição, ou um mal. Demais desse contato indistinto dos homens ali presos, que não podem coibir as más ações dos pretos, resultam o se irem acostumando a olhar com indiferença atos, que o homem de brio não poderia suportar, e dessa maneira em vez da pena de prisão reformar o caráter do delinqüente, moralizando-o, bem antes o perverteria; ora se as prisões não podem desde já por muitas circunstâncias ser a escola da oral para aqueles que se hão corrompido pelo vício, não o sejam elas ao menos da imoralidade" (Relatório da 
Comissão de Inspeção da Cadeia Pública de São Paulo, de agosto de 1834, apud Salla, 1999: 35 e 42).

Ao longo do século XIX, o discurso reformista do sistema penal mantém essa lógica dual para as penas. Porém, as propostas de adoção de códigos penais diferentes para homens livres e escravos não serão aprovadas, tal como as demais propostas de codificação jurídica das relações entre senhores e escravos. A não codificação das relações de senhores e escravos pode ser explicada pela divisão arquitetônica entre poder público e poder doméstico, a resistência dos senhores no sentido de preservar a autonomia das relações sociais domésticas e locais, e o discurso do paternalismo, que projetava as relações dos senhores com os escravos para os homens livres e pobres. O fracasso aparente da codificação daquelas relações vincula-se, assim, à rejeição, pelos senhores, da adoção de regras jurídicas fixas e claras para suas relações com indivíduos de condição social desigual, e 238 a preservação da submissão produtiva dos indivíduos pelo discurso do paternalismo.

Em suma, a dualidade das punições fundamenta-se nas diferenças de estatuto jurídico e condição social dos indivíduos, mas seu escopo é indeterminado, possibilitando a sua utilização para os indivíduos não-localizáveis naquela estrutura social. A partir da década de 1870, essa dualidade será formulada no interior do quadro teórico do positivismo, e as distinções da penalidade serão baseadas em teorias evolucionistas e racistas, as quais propõem medidas para "tratar desigualmente os desiguais", dentro de um ordenamento de igualdade jurídica de todos os indivíduos (Alvarez, 2002 e 2003).

A lógica dual das punições no discurso penal, seus efeitos para as práticas punitivas estatais e as articulações destas com a disciplina escravista, são reveladoras da tecnologia política do corpo na sociedade brasileira do século XIX. Assim, na estratégia política da sociedade escravista 
brasileira, são combinadas, por um lado, práticas punitivas estatais e mecanismos sociais de sujeição que se aplicam de forma diferente sobre indivíduos com estatuto jurídico ou categorias sociais distintas e, por outro lado, a lógica dual do direito penal, cujas categorias e propósitos são a correção moral ou a intimidação, segundo os indivíduos a que se dirigem. Essa lógica dual permite que o discurso penal compatibilize suas próprias categorias com saberes práticos de conhecimento dos indivíduos formados nos estabelecimentos prisionais, nas organizações estatais de vigilância e nas plantações. Essa é uma estratégia de conjunto, que incide sobre o comportamento dos escravos e outros subordinados, com o objetivo de obter a sua submissão produtiva à ordem social.

\section{Andrei Koerner}

é professor do Departamento de Ciência Política da Universidade Estadual de Campinas - Unicamp

\section{Referências bibliográficas}

ALENCASTRO, Luiz Felipe de. 1979. "La traite negrière et l"Unité Nationale Brésilienne". Revue Française d"Histoire d"Outre-Mer, t. LXVI, n. 244-245, pp. 395-419.

ALGRANTI, Leila M. 1988. O feitor ausente - estudo sobre a escravidão urbana no Rio de Janeiro - 1808-1822. Petrópolis: Vozes.

ALVAREZ, Marcos Cesar. 2003. Bacharéis, criminologistas e juristas: saber jurídico e nova escola penal no Brasil (1899-1930). São Paulo: Ed. do IBCCrim. . 2002. "A Criminologia no Brasil ou como tratar desigualmente os desiguais". Dados - Revista de Ciências Sociais, vol. 45, n. 4, pp. 677-704.

AUFDERHEIDE, Patrícia. 1976. Order and violence. social deviance and social control in Brazil - 1780-1840. Tese de Doutorado em História. Universidade de Minnesota, EUA.

BANDEIRA FILHO, Antônio Herculano S. 1881. A questão penitenciária no Brasil. Rio de Janeiro: Typ. de R.D. de Oliveira. 
BRITO, José Gabriel Lemos. 1924-1925-1929. Os sistemas penitenciários do Brasil. Rio de Janeiro: Imp. Nacional. 3 vols.

BRASIL - Ministério da Justiça. 1874. "Relatório da Comissão Inspetora da Casa de Correção da Corte”. Relatório apresentado à Assembléia Geral Legislativa na Terceira sessão da Décima Quinta Legislatura pelo Ministro e Secretário de Estado dos Negócios da Justiça, Dr. Manoel Antônio Duarte de Azevedo. Rio de Janeiro: Typ. Americana.

. 1838-1888. Relatórios apresentado à Assembléia Geral Legislativa pelo Ministro e Secretário de Estado dos Negócios da Justiça. Rio de Janeiro: Typ. Imperial.

CHALOUB, Sidey. 1990. Visões da liberdade. São Paulo: Companhia da Letras. $287 \mathrm{p}$.

CONRAD, Robert. 1985. Tumbeiros - O tráfico escravista para o Brasil. São Paulo: Brasiliense.

FOUCAULT, Michel. 1973. A verdade e as formas jurídicas. Rio de Janeiro: Ed. PUC. 1975. Surveiller et punir naissance de la prison. Paris: PUF. . 1979. "A governamentalidade". In: Microfi-

sica do poder. Rio de Janeiro: Graal. pp. 277 e ss.

240 In: DREYFUS, H.; RABINOW, P. Michel Foucault: un parcours philosophique: au delà de l"objectivité et de la subjectivité. Paris: Gallimard. pp. 297-321. . 1984b. "Sur la généalogie de l"ethique: un aperçu du travail en cours, entretien avec Hubert Dreyfus et Paul Babinow". In: DREYFUS, H.; RABINOW, P. Michel Foucault: un parcours philosophique: au delà de l"objectivité et de la subjectivité. Paris: Gallimard. pp. 322-346.

. 1990. "Omnes et Singulatim: Por uma Crítica da "Razão Política””. Novos Estudos CEBRAP, n. 26, pp. 77-99, março.

FRAGA FILHO, Walter. 1996. Mendigos, moleques e vadios na Bahia do século XIX. São Paulo: Hucitec/Salvador: Edufba.

FRANCO, Maria Sylvia de Carvalho. 1974. Homens livres na ordem escravocrata. 2. ed. São Paulo: Ática.

GOULART, José Alípio. 1971. Da palmatória ao patíbulo (castigos de escravos no Brasil). Rio de Janeiro: Conquista.

GRAHAM, Richard. 1990. Patronage and politics in nineteenth-century Brazil. Stanford: Stanford U.P. [Edição brasileira: Clientelismo e política no Brasil do século XIX. Rio de Janeiro: Ed. UFRJ, 1997.]

HOLLOWAY, Thomas. 1993. Policing Rio de Janeiro: repression and resistance in 19th-century city. Stanford: Stanford U.P. [Edição brasileira: A polícia do Rio de Janeiro. Ed. UFRJ.] 
HUGGINS, Martha K. 1984. From slavery to vagrancy in Brazil. Crime and social control in third world. New Jersey: Rutgers U.P.

KARASCH, Mary. 2000. A vida dos escravos no Rio de Janeiro (1808-1850). São Paulo: Companhia das Letras.

KOERNER, Andrei. 1998a. Judiciário e cidadania na Constituição da República Brasileira. São Paulo: Hucitec/Depto de Ciência Política da FFLCH/USP. . 1998b. O habeas-corpus na prática judicial Brasileira. Tese de doutorado em Ciência Política. São Paulo: FFLCH-USP. . 1999. Habeas-corpus, prática judicial e controle social no Brasil (1841-1920). São Paulo: Ed. do IBCCrim.

. 2001. "O impossível panóptico tropical-escravista: práticas prisionais, política e sociedade no Brasil do século XIX”. Revista Brasileira de Ciências Criminais, n. 35, jul./set.

KOWARICK, Lúcio. 1994. Trabalho e vadiagem: a origem do trabalho livre no Brasil. 2. ed. Rio de Janeiro: Paz e Terra.

LARA, Silvia. 1988. Campos da violência - escravos e senhores na capitania do Rio de Janeiro - 1750-1808. Rio de Janeiro: Paz e Terra.

MALERBA, Jurandir. 1994. Os brancos da lei: liberalismo, escravidão e mentalidade patriarcal no Império do Brasil. Maringá: Eduem.

MARQUESE, Rafael. 2004. Feitores do corpo, missionários da mente - senhores, letrados e o controle dos escravos nas Américas. São Paulo: Companhia das Letras. MATTOSO, Katia Queiroz. 1995. Etre esclave au Brésil. s.l.: Ed. Harmattan.

Moraes, Antônio Evaristo de. 1923. Prisões e Instituições Penitenciárias no Brasil. Rio de Janeiro: Livr. Ed. Cons. Candido de Oliveira.

NOVAIS, Fernando. s.d. Portugal e Brasil na crise do antigo sistema colonial (1777-1808). São Paulo: Hucitec. 420p.

PESSOA, Gláucia Tomaz de Aquino. 1994. "Fernando de Noronha, Uma IlhaPresídio nos Trópicos, 1833-1894”. Cadernos de Pesquisa. Rio de Janeiro: Arquivo Nacional, n. 1. 85p.

PESSOA, Vicente Alves de Paula. 1899 [1882]. Código de Processo Criminal de Primeira Instância do Império do Brasil com a Lei de 03 de dezembro de 1841, n. 261 e Regulamento n. 120, etc. 2. ed. Rio de Janeiro: Livraria de A. A.Cruz Coutinho Livreiro-Editor.

SALLA, Fernando. 1999. As prisões em São Paulo. São Paulo: Ed. Annablume/Fapesp.

SCHWARZ, Roberto. 1977. Ao vencedor as batatas: forma literária e processo social nos inícios do romance brasileiro. São Paulo: Liv. Duas Cidades. . 1998. Um mestre na periferia do capitalismo: Machado de Assis. São Paulo: Duas Cidades.

SILVA, Mozart Linhares da. 2003. O império dos bacharéis - o pensamento jurídi- 
co e a organização do Estado-nação no Brasil. Curitiba: Juruá.

SOUZA, Laura de Mello e. 1986. Desclassificados do ouro - a pobreza mineira no século XVIII. 2. ed. Rio de Janeiro: Graal.

STEIN, Stanley. 1990. Vassouras - um município brasileiro do café: 1850-1900. 2. ed. Rio de Janeiro: Nova Fronteira.

TOLEDO, Manoel Dias de. 1878. Lições acadêmicas sobre artigos do Código Criminal conforme foram explicadas na Faculdade de Direito de São Paulo. 2. ed. Rio de Janeiro: Garnier. [Edição mais correta com alterações e modificações pelo Bel. Manoel Januário Bezerra Montenegro.] 


\section{PUNIÇÃO, DISCIPLINA E PENSAMENTO PENAL NO BRASIL DO SÉCULO XIX}

\section{ANDREI KOERNER}

A partir da análise da relação entre práticas punitivas estatais, disciplina escravista e discurso jurídico no Brasil do século XIX, o artigo afirma a fecundidade da perspectiva foucaultiana para a análise das práticas de produção da sujeição e do discurso jurídico na sociedade contemporânea. O trabalho sugere a necessária articulação entre os temas e métodos postos por Foucault e os resultados de pesquisas históricas sobre as especificidades estruturais e culturais da sociedade brasileira.

Palavras-chave: Práticas Punitivas do Estado; Disciplina Escravista; Discurso Jurídico; Brasil do Século XIX; Michel Foucault. 


\section{PUNISHMENT, DISCIPLINE AND PENAL THOUGHT IN $19^{\text {TH }}$ CENTURY BRAZIL}

Out of the analysis of the relation between state practices of punishment, slaverist discipline and legal discourse in nineteenthcentury Brasil, the article underlines the significance of the Foucaultian perspective to understand the practices of both the production of subjection and the legal discourse in contemporary societies. The text suggests the necessary articulation between the issues and methods proposed by Foucault, and the results of the historical research about the structural and cultural particularities of the Brazilian society.

Keywords: State Practices of Punishment; Slaverist Discipline; Legal Discourse; Nineteenth-Century Brazil; Michel Foucault. 